\title{
Corneal Topographic Changes After Two Different Grafting Pterygium Surgery Techniques
}

\author{
Sabreen A Omar, Abdalla M Abdalla, Abdul Mongi E Ali, Ahmed F Gabr* \\ Department of Ophthalmology - Faculty of Medicine, Aswan University, Aswan, Egypt \\ *Corresponding author: Ahmed Fathy Gabr, FRCSEd, MD, Mobile: +201223496297, E-mail: drafgabr@yahoo.com
}

\begin{abstract}
Background: Surgical treatment of pterygium can result in corneal topographic changes. It is not clear that those changes are universal or technique dependent.

Objectives: Evaluation of corneal topographic changes following pterygium surgery using sutured conjunctival autografting versus sutured amniotic membrane grafting.

Patients and methods: In this prospective randomized study, patients suffering from primary pterygia that extend between two and four millimeters over the cornea were included. Patients were separated into group I; underwent pterygium excision with sutured conjunctival autograft, and group II underwent pterygium excision with sutured amniotic membrane graft after a comprehensive ophthalmic examination. The following topographic parameters were noted: the axial curvature map, elevation posterior map, and corneal thickness map.

Results: Significant improvement of the mean visual acuity measured using the logMAR test was found in both groups postoperatively. The improvement included UCVA and BCVA as well as anterior keratmetric and cylindrical power of the cornea without significant dissimilarity between study groups. No statistically considerable changes in the posterior corneal surface or the corneal thickness were found.

Conclusions: Pterygium excision can cause changes in the keratmetric and cylindrical power of the cornea without the affection of the posterior corneal surface or the corneal thickness. The corneal topographic changes caused by the pterygium were not varied with the type of surgical technique used.
\end{abstract}

Keywords: Amniotic membrane, conjunctival autograft, pterygium, corneal topography.

\section{INTRODUCTION}

Surgical excision remains the main treatment for pterygium causing impaired vision, cosmetic deformity, restriction of ocular motility, and/or marked irritation unrelieved by medical management ${ }^{(\mathbf{1})}$.

To reduce the rate of recurrence following surgical treatment of pterygium, various techniques have been applied which include pterygium resection combined with conjunctival auto-graft, amniotic membrane graft, or with stem cell transplantation ${ }^{(2)}$.

Refractive and topographic changes possibly occur as a result of pterygium existence or due to surgical interference for its management ${ }^{(3)}$. Previous studies tried to correlate the degree of spherocylindrical changes to the technique of surgical removal used keratometric values only ${ }^{(4)}$. Scheimpflug topographer imaging system was reported to accurately determine different corneal characteristics as curvature and topography of anterior and posterior corneal surface as well as its thickness ${ }^{(5)}$.

This study intended to evaluate the different corneal topographic changes following pterygium excision using two grafting techniques and their refractive outcome.

\section{PATIENTS AND METHODS}

In this perspective, controlled, randomized study (randomization was achieved using a software computer program); voluntary patients aged 20 - 60 years old and suffering from primary pterygia that extend between two and four millimeters over the cornea were included. After a full explanation about the nature of the procedure used written consents were taken from the patients before surgery.

History of ocular trauma, ocular surgery, recurrent pterygium, and presence of corneal abnormalities such as scarring was accepted as exclusion criteria. Included patients were allocated into two groups: group I; comprised 20 eyes that underwent pterygium excision with sutured conjunctival autograft, and group II comprised 20 eyes that underwent pterygium excision with sutured amniotic membrane graft.

After obtaining the required consent, complete medical and ocular history was taken from all patients. Then they were exposed to comprehensive ophthalmic examination including visual acuity [uncorrected (UCVA) and best-corrected (BCVA)], refraction, tonometry, as well as slit-lamp examination. Computerized video keratography (Scheimpflug topographer TMS -5, Tomey Gmbh Technology, and vision, Nurnberg, Germany) was obtained before the surgery.

The following topographic parameters were noted: the axial curvature map [steep axis of curvature $(\mathrm{Ks})$, the flat axis of curvature (Kf), average $\mathrm{K}$ and corneal astigmatism (Cyl)], elevation posterior map (Ks, $\mathrm{Kf}$, average $\mathrm{K}, \mathrm{Cyl}$ ), corneal thickness map (apex and thinnest location).

\section{Intraoperative:}

This article is an open access article distributed under the terms and conditions of the Creative Commons Attribution (CC BY-SA) license (http://creativecommons.org/licenses/by/4.0/) 
Twenty eyes underwent pterygium excision with conjunctival autograft, the other twenty eyes underwent pterygium excision with amniotic membrane graft. Surgical procedures were performed under local anesthesia (peribulbar anesthesia). The peeling of pterygium off the cornea followed by excision of its body was done. The area of the bare sclera was covered using superior temporal conjunctival autograft in group I; or using a lyophilized amniotic membrane (Biomembrane freeze-dried sterile human amnion membrane, National Center for Radiation Research) in group II. Either type of graft was then sutured using 8/0 vicryl suture (AssuCryl ${ }^{\circledR}$, Assut Medical, Switzerland) and the eye was patched.

\section{Postoperative:}

For all eyes in both groups, combined steroid and antibiotic eye drops were prescribed four times daily to all patients postoperatively $\left(\right.$ Tobradex $^{\circledR}$, Alcon Laboratories, Inc., Fort Worth, Texas, USA). Follow up was started one day, one week, one month, and three months postoperatively. During each visit, patients were evaluated clinically, and corneal topography was repeated by the end of the 3rd month.

\section{Ethical consideration:}

Protocols of the study were following the tenets of the Helsinki declaration and were approved by the ethical committee and the Institutional Review Board of Aswan univeristy. Confidentiality of all data was ensured at every step of the study.

\section{Statistical analysis:}

The arithmetic mean, standard deviation, and other tests as the unpaired student's ( $\mathrm{t}$ ) test, Wilcoxon ranks test, Fisher's exact test, Yates corrected Chi-square, and Mann-Whitney test was used for statistical analysis of the result of this study when appropriate. Probability (P) value $<0.05$ was reported significant. SPSS program, Version 16.0, Chicago, IL, USA was used.

\section{RESULTS}

In this present study forty eyes of 40 patients with primary pterygia underwent pterygium surgery, they were classified into 2 groups; group I: including 20 eyes who underwent excision of pterygium using sutured conjunctival autograft (CAG), and group II: including 20 eyes who underwent pterygium excision with sutured amniotic membrane graft (AMG).

There was no difference between both study groups as regards to age, gender, or duration of pterygium (Table 1).

In group, I significant improvement in visual acuity (UCVA and BCVA) was recorded and was found to be associated with a marked decrease in the mean spherical equivalent postoperatively compared to preoperative figures. Also, significant changes in anterior surface topographic parameters were found with an increase in $\mathrm{K}$ reading particularly with steeping in the flatter meridian (Kf). This resulted in a significant decrease in the cylindrical power of the cornea. On the other hand, no significant changes were noted in the posterior surface keratometric power or thickness of the cornea (Table 2).

Similar results were found in group II with significant improvement in visual acuity (UCVA and BCVA) and marked decrease in the mean spherical equivalent postoperatively compared to preoperative findings. Moreover, significant changes in anterior surface keratometric readings particularly with steeping in the flatter meridian (Kf) and a significant decrease in the cylindrical power of the cornea. Also, there were no significant changes in the posterior surface keratometric power or thickness of the cornea (Table 3 ).

Comparing both studied groups as regards UCVA as well as BCVA measured with LogMAR, there were no statistically significant differences pre or postoperative (P-value 0.521 and 0.236 respectively). Also, no difference in spherical equivalent was noted between both groups postoperatively ( $\mathrm{p}$-value 0.098) even though a mild significant difference in the basic preoperative spherical equivalent was found between them (p-value 0.043) (Table 4).

Study groups revealed no differences in keratometric parameters before surgery as regards to both steep and flat posterior curvatures. The lack of significant disparity between both groups was also extended postoperatively. Moreover, no significant difference was found between group I and group II when corneal thickness (apical and thinnest point) was compared pre and postoperatively (Table 5).

Table (1): Demographic differences between group I (conjunctival autografting), and group II (amniotic membrane grafting).

\begin{tabular}{|l|l|c|c|c|}
\hline \multicolumn{2}{|c|}{} & Group I (n=20) & Group II (n=20) & P-value \\
\hline Age & Mean \pm SD & $42.8 \pm 9.7$ & $42.25 \pm 11.17$ & 0.869 \\
\hline \multirow{2}{*}{$\begin{array}{l}\text { Nex } \\
\text { No } \%)\end{array}$} & Male & $11(55 \%)$ & $10(50 \%)$ & 0.752 \\
\cline { 2 - 4 } $\begin{array}{l}\text { Eye } \\
\text { No }(\%)\end{array}$ & Female & $9(45 \%)$ & $10(50 \%)$ & \\
\hline Duration of pterygium (months) & Right & $8(40 \%)$ & $8(40 \%)$ & \multirow{2}{*}{1.000} \\
\cline { 2 - 4 } & Left & $12(60 \%)$ & $12(60 \%)$ & \\
\hline
\end{tabular}

Independent t-test, P-value significant $<0.05$. 
Table (2): Comparison between preoperative and postoperative visual acuity, spherical equivalent, corneal keratometric power and corneal thickness in group I (conjunctival autografting)

\begin{tabular}{|c|c|c|c|c|c|}
\hline 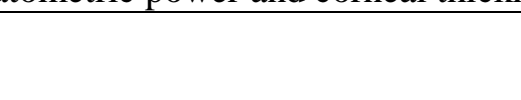 & & $\begin{array}{c}\text { Preoperative } \\
\text { Mean } \pm \text { SD }\end{array}$ & $\begin{array}{c}\text { Postoperative } \\
\text { Mean } \pm \text { SD }\end{array}$ & $\mathbf{z}$ & p-value \\
\hline VA $(\log M A R)$ & UCVA & $0.304 \pm 0.186$ & $0.219 \pm 0.140$ & 3.526 & 0.000 \\
\hline \multicolumn{2}{|l|}{ SE (diopter) } & $1.502 \pm 1.602$ & $0.983 \pm 1.371$ & 2.42 & 0.016 \\
\hline \multirow{4}{*}{$\begin{array}{l}\text { Keratometry } \\
\text { Power (diopter) }\end{array}$} & Ks & $45.36 \pm 2.57$ & $45.92 \pm 2.30 \mathrm{D}$ & 3.248 & 0.001 \\
\hline & $\mathrm{Kf}$ & $41.9 \pm 2.32$ & $43.73 \pm 2.55 \mathrm{D}$ & 3.92 & 0.00009 \\
\hline & Kav & $43.64 \pm 1.63$ & $44.83 \pm 2.26 \mathrm{D}$ & 3.92 & 0.00009 \\
\hline & CYL & $3.42 \pm 3.66$ & $1.95 \pm 1.33$ & 2.725 & 0.006 \\
\hline \multirow{4}{*}{$\begin{array}{l}\text { Posterior } \\
\text { (diopter) }\end{array}$} & Ks & $-.67 \pm 0.599 \mathrm{D}$ & $-6.64 \pm 0.668 \mathrm{D}$ & 0.299 & 0.765 \\
\hline & $\mathrm{Kf}$ & $-6.21 \pm 0.266$ & $-.245 \pm 0.282 \mathrm{D}$ & 0.897 & 0.37 \\
\hline & Kav & $-6.43 \pm 0.394$ & $-6.45 \pm 0.434$ & 0.037 & 0.97 \\
\hline & CYL & $0.538 \pm 0.593$ & $0.408 \pm 0.532$ & 1.048 & 0.295 \\
\hline Pachymetry $(\mu \mathrm{m})$ & $\begin{array}{l}\text { Apex } \\
\text { Thinnest }\end{array}$ & \begin{tabular}{|l|}
$542.6 \pm 59.02$ \\
$522.5 \pm 43.97$
\end{tabular} & $\begin{array}{l}539.1 \pm 59.31 \\
518.0 \pm 80.82\end{array}$ & $\begin{array}{l}0.691 \\
0.653\end{array}$ & $\begin{array}{c}0.49 \\
0.514\end{array}$ \\
\hline
\end{tabular}

$V A=$ visual acuity, $\log M A R$ (Logarithm of Minimal Resolution angle), UCVA (Uncorrected Visual Acuity), BCVA (Best Corrected Visual Acuity), $K s=$ steep keratometric axis, $K f=$ flat keratometric axis, $K a v=$ Keratometric average, $C Y L=$ cylinder, $D=$ diopter, $S E=$ spherical equivalent, $\mu \mathrm{m}=$ micrometer, $\mathrm{P}$ value $<0.05$ significant (Wilcoxon ranks test)

Table (3): Comparison between preoperative and postoperative visual acuity, spherical equivalent, corneal keratometric power, and corneal thickness in group II (amniotic membrane grafting)

\begin{tabular}{|c|c|c|c|c|c|}
\hline 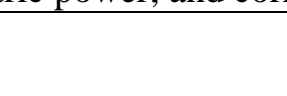 & & $\begin{array}{c}\text { Preoperative } \\
\text { Mean } \pm \text { SD }\end{array}$ & $\begin{array}{c}\text { Postoperative } \\
\text { Mean } \pm \text { SD }\end{array}$ & $\mathbf{z}$ & p-value \\
\hline \multirow[t]{2}{*}{ VA (logMAR) } & UCVA & $0.279 \pm 0.215$ & $0.189 \pm 0.153$ & 3.065 & 0.002 \\
\hline & BCVA & $0.115 \pm 0.129$ & $0.051 \pm 0.068$ & 2.740 & 0.006 \\
\hline \multicolumn{2}{|l|}{ SE (diopter) } & $0.396+3.485$ & $0.0110 \pm 3.188$ & 2.334 & 0.020 \\
\hline \multirow{4}{*}{$\begin{array}{l}\text { Keratometry } \\
\text { Power (diopter) }\end{array}$} & Ks & $45.05 \pm 2.10$ & $44.93+2.27$ & 1.642 & 0.1 \\
\hline & $\mathrm{Kf}$ & $42.74 \pm 2.65$ & $43.23+2.41$ & 3.174 & 0.002 \\
\hline & Kav & $43.89 \pm 2.23$ & $44.08+2.25$ & 3.174 & 0.002 \\
\hline & CYL & $2.31 \pm 1.72$ & $1.54+1.14$ & 2.763 & 0.006 \\
\hline \multirow{4}{*}{$\begin{array}{l}\text { Posterior } \\
\text { surface power } \\
\text { (diopter) }\end{array}$} & Ks & $-6.59 \pm 0.52 \mathrm{D}$ & $-6.47 \pm 0.33 \mathrm{D}$ & 1.064 & 0.287 \\
\hline & $\mathrm{Kf}$ & $-6.23 \pm 0.25 \mathrm{D}$ & $-6.18 \pm 0.29 \mathrm{D}$ & 0.645 & 0.519 \\
\hline & $\mathrm{Kav}$ & $-6.41 \pm 0.33 \mathrm{D}$ & $-6.33 \pm 0.27 \mathrm{D}$ & 1.008 & 0.313 \\
\hline & CYL & $0.368 \pm 0.468$ & $0.324 \pm 0.415$ & 0.205 & 0.837 \\
\hline $\begin{array}{l}\text { Pachymetry } \\
(\mu \mathrm{m})\end{array}$ & $\begin{array}{c}\text { Apex } \\
\text { Thinnest }\end{array}$ & \begin{tabular}{|l}
$558.3 \pm 66.83$ \\
$532.8 \pm 49.78$
\end{tabular} & $\begin{array}{l}556.8 \pm 60.28 \\
531.2 \pm 63.83\end{array}$ & $\begin{array}{l}0.168 \\
0.336\end{array}$ & $\begin{array}{l}0.867 \\
0.737\end{array}$ \\
\hline
\end{tabular}

$V A=$ visual acuity, logMAR (Logarithm of Minimal Resolution angle), UCVA (Uncorrected Visual Acuity), BCVA (Best Corrected Visual Acuity), $K s=$ steep keratometric axis, $K f=$ flat keratometric axis, $K a v=$ Keratometric average, $C Y L=$ cylinder, $D=$ diopter, $S E=$ spherical equivalent, $\mu \mathrm{m}=$ micrometer, $\mathrm{P}$ value $<0.05$ significant (Wilcoxon ranks test)

Table (4): Comparison between group I (conjunctival autografting) and group II (amniotic membrane grafting) as regards to visual acuity and spherical equivalent pre and postoperatively

\begin{tabular}{|c|c|c|c|c|c|c|c|c|c|}
\hline \multirow{3}{*}{ Item } & \multicolumn{4}{|c|}{ Preoperative } & \multicolumn{4}{|c|}{ Postoperative } & \multirow[b]{3}{*}{ Test } \\
\hline & \multicolumn{2}{|c|}{ Mean \pm SD } & \multirow[b]{2}{*}{$\mathbf{z}$} & \multirow[b]{2}{*}{$\begin{array}{c}\text { p- } \\
\text { value }\end{array}$} & \multicolumn{2}{|c|}{ Mean \pm SD } & \multirow[b]{2}{*}{$\mathbf{Z}$} & \multirow[b]{2}{*}{ p-value } & \\
\hline & Group I & Group II & & & Group I & Group II & & & \\
\hline $\begin{array}{l}\text { UCVA } \\
\text { (Log MAR) }\end{array}$ & $0.304 \pm 0.186$ & $0.279 \pm 0$ & 0.642 & 0.521 & $0.219 \pm 0.140$ & 0.189 & 0.999 & 0.318 & \multirow{3}{*}{$\begin{array}{c}\text { Mann- } \\
\text { Whitney } \\
\text { test }\end{array}$} \\
\hline $\begin{array}{l}\text { BCVA } \\
\text { (Log MAR) }\end{array}$ & $0.177 \pm 0.163$ & $0.115 \pm 0.129$ & 1.186 & 0.236 & $0.092 \pm 0.112$ & $0.051 \pm 0.068$ & 1.204 & 0.229 & \\
\hline SE & $1.502 \pm 1.602$ & $0.396 \pm 3.485$ & 2.019 & 0.043 & $0.983 \pm 1.371$ & $0.0110 \pm 3.188$ & 1.653 & 0.098 & \\
\hline
\end{tabular}

logMAR (Logarithm of Minimal Resolution angle), UCVA (Uncorrected Visual Acuity), BCVA (Best Corrected Visual Acuity), $S E=$ spherical equivalent, $\mathrm{P}$ value $<0.05=$ significant 
Table (5): Comparison between group I (conjunctival autografting) and group II (amniotic membrane grafting) as regards to keratometric and pachymetric parameters pre and postoperatively

\begin{tabular}{|c|c|c|c|c|c|c|c|c|c|c|}
\hline \multirow{3}{*}{\multicolumn{2}{|c|}{ Item }} & \multicolumn{4}{|c|}{ Preoperative } & \multicolumn{4}{|c|}{ Postoperative } & \multirow{3}{*}{ Test } \\
\hline & & \multicolumn{2}{|c|}{ Mean \pm SD } & \multirow[b]{2}{*}{$\mathbf{Z}$} & \multirow{2}{*}{ p-value } & \multicolumn{2}{|c|}{ Mean \pm SD } & \multirow[b]{2}{*}{$\mathbf{Z}$} & \multirow{2}{*}{$\begin{array}{c}\text { p- } \\
\text { value }\end{array}$} & \\
\hline & & Group I & Group II & & & Group I & Group II & & & \\
\hline \multirow{3}{*}{$\begin{array}{l}\text { Anterior } \\
\text { Keratometry }\end{array}$} & $\mathrm{Kf}$ & $41.9 \pm 2.32$ & $42.74 \pm 2.65$ & 1.298 & 0.194 & $43.73+2.55$ & $43.23+2.41$ & 0.46 & 0.646 & \multirow{6}{*}{$\begin{array}{c}\text { Mann- } \\
\text { Whitney } \\
\text { test }\end{array}$} \\
\hline & Kav & $43.64 \pm 1.63$ & $43.89 \pm 2.23$ & 0.433 & 0.665 & $44.83+2.26$ & $44.08+2.25$ & 0.839 & 0.402 & \\
\hline & CYL & $3.42 \pm 3.66$ & $2.31 \pm 1.72$ & 1.19 & 0.234 & $1.95+1.33$ & $1.54+1.14$ & 1.244 & 0.213 & \\
\hline \multirow{3}{*}{$\begin{array}{l}\text { Posterior } \\
\text { keratometry }\end{array}$} & Ks & $-6.67+0.6$ & $-6.59+0.52$ & 0.501 & 0.617 & $-6.64+0.67$ & $-6.47+0.33$ & 0.771 & 0.441 & \\
\hline & Kav & $-6.43+0.39$ & $-6.41+0.33$ & 0.122 & 0.903 & $-6.45+0.43$ & $-6.33+0.27$ & 0.717 & 0.473 & \\
\hline & CYL & $0.54+0.59$ & $0.37+0.47$ & 1.476 & 0.14 & $0.41+0.53$ & $0.32+0.42$ & 1.435 & 0.151 & \\
\hline \multirow[b]{2}{*}{ Pachymetry } & Apex & $542.55+59.02$ & $558.3+66.83$ & 0.906 & 0.365 & $558.3+66.83$ & $556.75+60.28$ & 0.168 & 0.867 & \multirow{2}{*}{$\begin{array}{l}\text { Wilcoxon } \\
\text { signed ranks }\end{array}$} \\
\hline & Thin & $522.45+43.97$ & $532.8+49.78$ & 0.582 & 0.561 & $532.8+49.78$ & $531.15+63.83$ & 0.336 & 0.737 & \\
\hline
\end{tabular}

$V A=$ visual acuity, $K s=$ steep keratometric axis, $K f=$ flat keratometric axis, $K a v=$ Keratometric average, $C Y L=$ cylinder,

$P$ value $<0.05=$ significant

\section{DISCUSSION}

Correlation between degrees of corneal parameters changes to particular techniques of pterygium excision surgery was infrequently discussed by previous studies. Some of them again used keratometric values only to confirm various changes ${ }^{(4)}$.

Using Scheimpflug topographer; the recent study tried to answer three questions; (1) is the change of the anterior corneal surface parameters following pterygium excision is technique dependant or not; (2) is there a change in central or apical corneal thickness related to pterygium excision; and (3) is there a change in posterior corneal parameters associated with pterygium excision? The study also investigated the effects of surgical treatment of pterygium on different aspects of visual performance.

Significant improvement of the mean visual acuity was found in the current study in both study groups postoperatively. The improvement included both UCVA and BCVA with no significant difference between both groups. Improvement in the visual acuity following surgical excision was owed in previous researches to reconstruction of the normal surface, improvement in the mean surface regularity index, surface asymmetry index as well as aberration coefficient ${ }^{(6,7,8)}$.

In a related study, Razmjoo et al. ${ }^{(9)}$ found that the UCVA and BCVA to be improved from $0.31 \pm 0.26$ and $0.19 \pm 0.21$ LogMar preoperatively to $0.14 \pm 0.17$ and $0.03 \pm 0.04$ LogMar postoperatively, respectively. This also agreed with other investigators who confirmed the previous results ${ }^{(\mathbf{1 0}, \mathbf{1 1})}$.

The amount of induced astigmatism was reduced postoperatively, so the topographic cylinder decreased significantly after removal of the pterygium in both groups, this result resembles that of Yagmar $\boldsymbol{e t}$ al. ${ }^{(12)}$ who found that the topographic cylinder changed from $4.65 \pm 3.02$ to $2.33 \pm 2.26 \mathrm{D}$ postoperatively. Comparable results were noted by other investigators as well ${ }^{(13)}$.

Lacking disparity between both groups; the spherical equivalent of manifest refraction was improved after surgery due to a decrease in astigmatism caused by the growth of the pterygium on the corneal surface. Kheirkhah et al. ${ }^{(14)}$ also found similar results in their study. They found a postoperative reduction of anterior corneal surface astigmatism of about 2.74 diopters. Similar findings were reported by other investigators ${ }^{(15,16)}$.

Garg et al. (17) found that using amniotic membrane graft and conjunctival autograft techniques supplementing pterygium excision surgeries were more effective in reducing astigmatism than pterygium excision surgery using bare sclera technique. But they reported no significant differences between both grafting techniques as regards to keratometric astigmatic reduction. This was also in agreement with the current study.

The mean keratometric power increased postoperatively in both operated groups as a result of the significant steepening of the flat meridian $(\mathrm{Kf})$ with no significant differences between the study groups using two different graft techniques. The postoperative changes in the steep meridian (Ks) could be due to the coupling effect on the cornea. These results were in agreement with that of Altan-Yaycioglu et al. ${ }^{(4)}$ who compared keratometric changes after five different surgical techniques using keratometry only and had no difference between all surgical methods used. Similar keratometric and topographic changes were reported in previous studies following merely the use of conjunctival autografts ${ }^{(15,18)}$ or with the use of different techniques ${ }^{(\mathbf{1 9})}$.

As anticipated, there were no statistically significant changes found in the posterior corneal surface parameters in the two studied groups preoperatively or postoperatively since surgical manipulations did not involve the posterior corneal surface. These results agree with Kheirkhah et al. ${ }^{(14)}$ results who reported insignificant decreased mean $\mathrm{K}$ of the posterior corneal surface changed from $0.35 \pm 0.39$ $\mathrm{D}$ preoperatively to $0.32 \pm 0.2 \mathrm{D}$ postoperatively. 
In the current study, no significant differences were found regarding postoperative apical corneal thickness from that of preoperative values in both conjunctival autograft and amniotic membrane groups. The difference between both groups was also not significant. Oltulu et $\boldsymbol{a l} .{ }^{(7)}$ investigated the changes caused by pterygium surgery on the cornea and anterior chamber using Pentacam without significantly different changes in anterior chamber parameters were found.

\section{CONCLUSIONS}

Pterygium excision can cause changes in the keratmetric and cylindrical power of the anterior corneal surface without the affection of the posterior cornea or the corneal thickness. The corneal topographic changes were equally not dependent on the type of graft techniques used.

\section{ACKNOWLEDGMENT}

The authors extend their acknowledgment to all staff members of the Department of Ophthalmology, Aswan University hospital.

\section{Declaration of interest:}

The authors report no conflict of interest.

This work was supported by resources of the Ophthalmology Department, Faculty of Medicine, Aswan University, Egypt.

\section{REFERENCES}

1. Clearfield E, Muthappan V, Wang $X$ et al. (2016): Conjunctival autograft for pterygium. Cochrane Database Syst Rev., 2: CD011349.

2. Akbari M, Soltani-Moghadam R, Elmi R et al. (2017): Comparison of free conjunctival autograft versus amniotic membrane transplantation for pterygium surgery. J Curr Ophthalmol., 29(4): 282-286.

3. Maheshwari S (2007): Pterygium-induced corneal refractive changes. Indian J Ophthalmol., 55(5):383-386.

4. Altan-Yaycioglu R, Kucukerdonmez C, Karalezli A et al. (2013): Astigmatic changes following pterygium removal: Comparison of 5 different methods. Indian $\mathrm{J}$ Ophthalmol., 61(3):104-108.

5. Ucakhan O, Gesog lu P, Ozkan M (2008): Corneal elevation and thickness in relation to the refractive status measured with the Pentacam Scheimpflug system. J Cataract Refract Surg., 34:1900-1905.

6. Oh J, Wee W (2010): The effect of pterygium surgery on contrast sensitivity and corneal topographic changes. Clin Ophthalmol., 4:315-319.

7. Oltulu T, Demirel S, Sarac O et al. (2013): Evaluation of corneal and anterior chamber changes following pterygium surgery using a Pentacam Scheimplug system: a prospective study. Semin Ophthalmol., 28(4):206-209.

8. Rohrbacher I, Mylla Boso P, de Almeida F et al. (2018): Analysis of corneal curvature after pterygium excision: the impact of the surgical procedure objectively in our practice. Rev Brasil Oftalmol., 77(2):65-67.

9. Razmjoo H, Vaezi M, Peyman A et al. (2014): The effect of pterygium surgery on wavefront analysis. Adv Biomed Res., 3:196.

10. Wu P, Kuo C, Hsu H et al. (2009): Effect of pterygium surgery on refractive spherocylinder power and corneal topography. Ophthalmic Surg Lasers Imaging, 40(1):3237.

11. Bahar I, Loyan N, Weinberger D et al. (2004): Effect of pterygium surgery on corneal topography: A prospective study. Cornea, 23:113-117.

12. Yagmur M, Altan A, Ozcan M et al. (2005): Visual acuity and corneal topographic changes related to pterygium surgery. J Refract Surg., 21:166-170.

13. Stern G, Lin A (1998): Correlation between pterygium size and induced corneal astigmatism. Cornea, 17:28-30.

14. Kheirkhah A, Safi H, Molaei S et al. (2012): Effects of pterygium surgery on front and back corneal astigmatism. Can J Ophthalmol., 47(5):423-428.

15. Errais K, Bouden J, Mili-Boussen I et al. (2008): Effect of pterygium surgery on corneal topography. Eur $\mathrm{J}$ Ophthalmol., 18(2):177-181.

16. Khan F, Niazi S, Khan D (2014): The Impact of Pterygium Excision on Corneal Astigmatism. J College Phys Surg Pakistan, 24(6):404-407.

17. Garg P, Sahai A, Shamshad M et al. (2019): A comparative study of preoperative and postoperative changes in corneal astigmatism after pterygium excision by different techniques. Indian J Ophthalmol., 67:10361069.

18. Ignatz R, Pedro F, Fernanda B et al. (2018): Analysis of corneal curvature after pterygium excision: the impact of the surgical procedure objectively in our practice. Rev Brasil Oftalmol, 77(2):65-67.

19. Yilmaz S, Yuksel T, Maden A (2008): Corneal topographic changes after four types of pterygium surgery. J Refract Surg., 24(2):160-165. 